\title{
PERAN KETERLIBATAN KONSUMEN DALAM PEMBELIAN AKSESORI FOTOGRAFI
}

\author{
Retno Dewanti; Nicky Agathon Sebastian; Rita \\ Jurusan Manajemen, Fakultas Ekonomi dan Komunikasi, BINUS University \\ Jln. K.H. Syahdan No. 9, Palmerah, Jakarta Barat 11480 \\ retnodewanti@binus.edu
}

\begin{abstract}
Nowadays Consumer Involvement, in the midst of business competition, becomes an interesting topic to discuss. The level of consumer involvement can be based on the value and the needs felt by the consumers themselves. The purpose of this research is to analyze the influence of Promotional Mix and Situational Context toward the consumer involvement and its impact on the purchase decision on photography accessories. The data was gathered from a photography fan community. The method used on this research is Path Analysis in order for us to know about the purchase decision making based on two variables, they are, the indirect impact of promotional mix towards the purchase decision and the indirect impact of situational context towards the purchase decision. The analyzed data shows that, together, promotional mix and situational context are affecting the photography consumers' involvement and they create an impact on photography accessories purchase decision.
\end{abstract}

Keywords: promotional mix, situational context, consumer involvement, purchase decision, photography

\begin{abstract}
ABSTRAK
Keterlibatan konsumen sekarang ini menjadi salah satu perbincangan yang menarik di tengah persaingan bisnis. Tinggi rendahnya tingkat keterlibatan konsumen dapat didasari pada nilai dan kebutuhan yang dirasakan oleh konsumen itu sendiri. Tujuan penelitian ini adalah menganalisis pengaruh bauran promosi (Promotional-mix) dan konteks situasi (Situational Context) terhadap keterlibatan konsumennya (Involvement) serta dampaknya bagi keputusan pembelian aksesori fotografi. Data diperoleh dari komunitas penggemar fotografi. Metode yang digunakan dalam penelitian ini adalah Path Analysis untuk mengetahui jalur penentu keputusan pembelian berdasarkan dua variable yakni pengaruh tidak langsung promotional mix terhadap keputusan pembelian dan pengaruh tidak langsung konteks situasional terhadap keputusan pembelian. Analisis data menunjukkan bahwa bauran promosi bersama sama dengan konteks situasional berpengaruh terhadap keterlibatan konsumen fotografi dan berdampak pada keputusan pembelian aksesori fotografi.
\end{abstract}

Kata kunci: bauran promosi, situasi, keterlibatan, pembelian, fotografi 


\section{PENDAHULUAN}

Salah Satu peluang bisnis yg sedang berkembang pesat sekarang adalah bisnis fotografi. Laporan statistik dari Camera \& Imaging Products Association (CIPA) menyatakan bahwa penjualan kamera DSLR global pada 2009 bertumbuh 102,3\% dan CIPA yakin bahwa angka ini akan terus naik hingga $111,1 \%$ pada 2010 . Hal juga ini berdampak pada pertumbuhan komunitas fotografi dan pengguna DSLR. Salah satu komunitas fotografi online adalah Fotografer.Net, terbesar di Indonesia, memiliki 233.149 member pada April 2009 dan 92.783 diantaranya adalah member aktif. Di dalam komunitas tersebut, terdaftar, terdapat 35.859 topik forum dengan lebih dari 1 juta komentar, 769.027 buah foto, dan 12 juta kritik foto. Dari data tersebut dapat disimpulkan bahwa jumlah peminat fotografi selalu bertambah dari waktu ke waktu.

Bisnis fotografi memiliki beberapa strategi untuk meningkatkan penjualannya. Salah satu bentuk usahanya adalah dengan mengikutsertakan konsumennya, Untuk itu penting merumuskan strategi yang tepat dalam memilih dan mengkombinasikan program bauran promosi yakni Personal Selling, Public Relation, dan Sales Promotion. Program bauran promosi tersebut akan mampu menjadi kekuatan industri fotografi bila diimplementasikan pada situasi yang tepat sehingga konsumen memiliki kekesuaian perhatian yang menjadikannya terlibat pada situasi tersebut dan melakukan pembelian.

Berdasarkan studi literatur dinyatakan oleh Kotler dan Amstrong (2004), Tjiptono (2008), Wardani (2003), dan Bowdin (2002) bahwa kegiatan bauran promosi pada hakekatnya adalah kegiatan untuk menarik perhatian konsumen yang mengakibatkan kenaikan penjualan. Namun niat pembelian tergantung pada unsur-unsur pada lingkungan yang menjadi situasi penentu yang mampu merubah perilaku pembelian antara lain lingkungan fisik, sosial, tekanan waktu, situasi pembeliaan dan situasi penggunaan (Carrington, 1975; Belk , 2010; Hawkins, Motherbaugh dan Best, 2007). Oleh karena itu, ketertarikan konsumen terhadap produk, perlu didukung oleh pesan yang memadai dan pada konteks situasi pembelian yang sesuai yakni sesuai dengan relevansi pribadi konsumennya dan situasi konsumennya (Solomon, 2007; Peter \& Olson, 2007). Konsumen membeli produk karena memutuskan adanya pilihan yang menarik diantara alternative yang ada. (Schiffman dan Kanuk, 2000; Schermerchon, 2002). Alternatif pilihan disajikan secara persuasive melalui bauran promosi (Belch \& Belch, 2007).

\section{Kerangka Pemikiran}

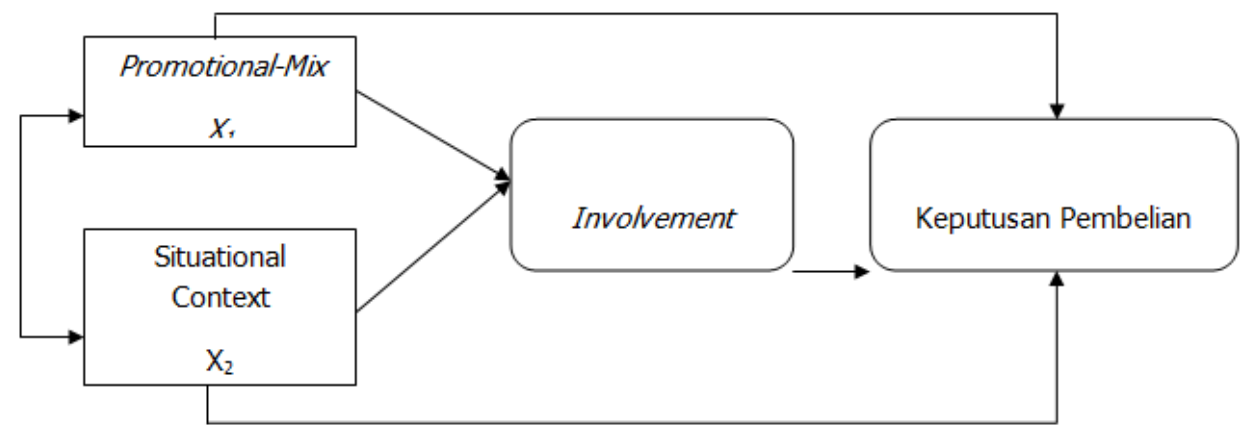

Gambar 1 Bagan kerangka pemikiran 


\section{Hipotesis}

Penelitian ini bertujuan untuk mengetahui peran Bauran promosi dan situasi terhadap keterlibatan konsumen, serta menguji keterlibatan konsumen tersebut sebagai variabel intervening yang memperantarai efektivitas bauran promosi dan situasi terhadap keputusan pembelian aksesori fotografi.

\section{HASIL DAN PEMBAHASAN}

Berdasarkan pengambilan data berdasarkan kuesioner kepada pelanggan aksesori fotografi diketahui profil responden antara lain mayoritas penyuka fotografi adalah pria, dengan usia antara 3140 tahun. Dapat dideskripsikan pembuktian hipotesis.

\section{Analisis Pengaruh Promotional-mix dan Situational Context terhadap Involvement.}

Sebelum melakukan analisis, akan ditampilkan terlebih dahulu struktur hubungan kausal antara variabel Promotional-mix (X1), Situational Context (X2), Involvement (Y), dan Keputusan Pembelian (Z) dalam Gambar 2.

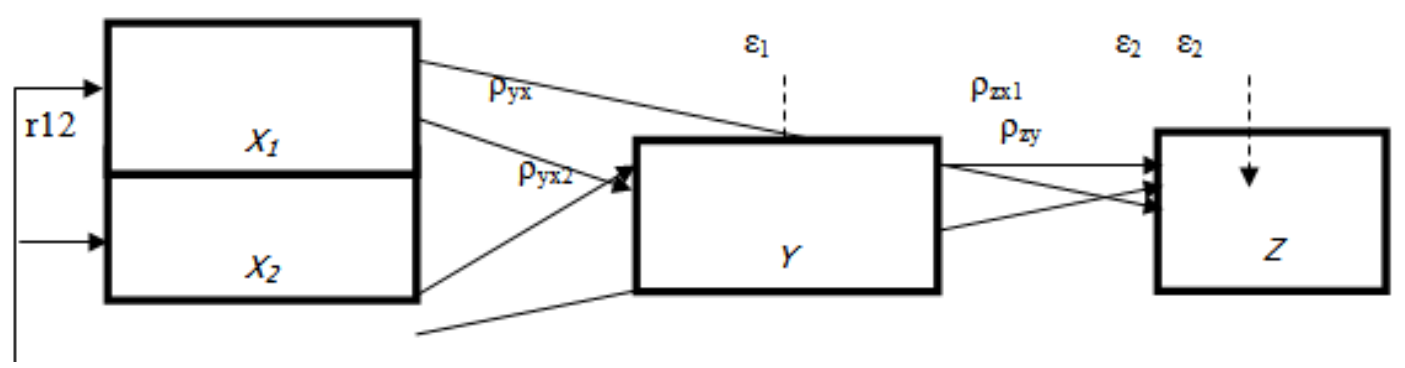

Gambar 2 Causalitas variabel

Tabel 3 Korelasi X1, X2, dan Y

\begin{tabular}{ccc}
\hline Hubungan antara & Korelasi & Sifat Hubungan \\
\hline X1 dengan X2 & 0,327 & Lemah dan Searah \\
X1 dengan Y & 0,548 & Cukup kuat dan Searah \\
X2 dengan Y & 0,450 & Lemah dan Searah \\
\hline
\end{tabular}

Kerangka hubungan kausal empiris antara $X_{1}$ dan $X_{2}$ terhadap $Y$ dapat dibuat melalui persamaan struktural sebagai berikut:

$$
\mathrm{Y}=0.613 \times 1+0.510 \times 2+0.6892 \varepsilon_{1} \text { dimana } \mathrm{R}^{2}: 0,525
$$


Kerangka hubungan antara jalur variabel Promotional-mix $\left(X_{1}\right)$ terhadap Keputusan Pembelian $(Z)$, Situational Context $\left(X_{2}\right)$ terhadap Keputusan Pembelian $(Z)$, dan Involvement $(Y)$ terhadap Keputusan Pembelian $(Z)$ dapat dibuat melalui persamaan struktural sebagai berikut.

$$
Z=0,377 x 1+0,410 x 2+0,582 y+0,5907 \varepsilon_{2} \text { dimana } R^{2}: 0,651
$$

Berdasarkan hasil keseluruhan pengaruh kausal variabel Promotional-mix $\left(X_{1}\right)$ dan Situational Context $\left(X_{2}\right)$ terhadap Involvement $(Y)$ dan dampaknya terhadap Keputusan Pembelian $(Z)$ adalah perhitungan analisis jalur struktural sebagai berikut.

\section{Promotional-mix $\left(X_{1}\right)$ berkontribusi positif dan signifikan terhadap Involvement $(Y)$}

Hasil penelitian menunjukan bahwa Promotional-mix berkontribusi positif dan signifikan terhadap tinggi rendahnya Involvement. Besarnya kontribusi Promotional-mix terhadap Involvement adalah sebesar $0,613^{2}$ X $100 \%=37,58 \%$ dan hubungan antar kedua variabel adalah hubungan yang cukup kuat, yaitu sebesar 54.8\%. Promotional-mix ini melibatkan Sales Promotion, Personal Selling dan Public Relation, yang dimana semuanya itu memiliki tujuan untuk menyebarluaskan informasi guna meningkatkan keterlibatan konsumen. Salah satu bentuk media komunikasi yang ditawarkan oleh Prima Imaging sebagai bentuk strategi promosinya selain promosi penjualan adalah dengan mengadakan event-event yang interaktif dan menarik. Hal ini berarti jika Prima Imaging ingin meningkatkan tingkat keterlibatan pelanggannya maka salah satu caranya adalah dengan mengadakan event yang interaktif yang dipadukan juga dengan promosi penjualan yang menarik dengan jangka waktu promosi yang tepat.

\section{Situational Context $\left(\mathrm{X}_{2}\right)$ berkontribusi positif dan signifikan terhadap Involvement $(\mathrm{Y})$}

Hasil penelitian menunjukan bahwa kompetensi individu berkontribusi positif dan signifikan terhadap tinggi rendahnya Involvement. Besarnya kontribusi service quality terhadap motivational values adalah sebesar $0,510^{2}$ X $100 \%=26,01 \%$ dan hubungan antar kedua variabel adalah hubungan kuat, yaitu sebesar 45\%. Situational Context melibatkan lingkungan fisik, lingkungan sosial, tekanan waktu, situasi pembelian dan lainnya, yang dimana semuanya itu memiliki pengaruh yang penting bagi penilaian secara emosional yang bisa menentukan keterlibatan seorang konsumen. Seperti contohnya, lingkungan fisik terdifinisi dari lokasi dan tata ruang dalam sebuah perusahaan, Seorang konsumen dapat bertahan lebih lama apabila lokasi perusahaan tersebut strategis/mudah dijangkau dan tata ruang dalamnya nyaman. Selain dari sisi fisik, lingkungan sosial juga memiliki peranan yang penting juga. Yakni dengan adanya komunikasi atau pembicaraan secara formal maupun informal yang kondusif yang terjadi dalam perusahaan dapat mendukung konsumen untuk terlibat lebih dalam.

Selain dari lingkungan fisik dan juga lingkungan sosial, tingkat keterlibatan seorang konsumen juga dapat dipengaruhi oleh faktor situasi pembelian yang berpengaruh pada tingkat kebutuhan konsumen. Konsumen akan semakin terlibat, apabila sebuah perusahaan berhasil memenuhi segala kebutuhan konsumen dalam setiap situasi pembelian yang berbeda-beda (Peter \& Olson, 2007). Hal ini berarti jika Prima Imaging ingin meningkatkan tingkat keterlibatan konsumennya melalui tingkat pengaruh Situational Context maka Prima Imaging perlu untuk memperhatikan kondisi lingkungan yang ada di sekitarnya, mulai dari tata ruang hingga situasi sosial yang terbentuk pada saat melangsungkan sebuah acara.

\section{Promotional-mix $\left(X_{1}\right)$ berkontribusi positif dan signifikan terhadap Keputusan Pembelian $(Z)$}

Hasil penelitian menunjukan bahwa Promotional-mix berkontribusi positif dan signifikan terhadap tinggi rendahnya Keputusan Pembelian. Besarnya kontribusi Promotional-mix terhadap Keputusan Pembelian secara simultan adalah sebesar $0,377^{2}$ X $100 \%=14,21 \%$ serta besar kontribusi secara tidak langsung adalah sebesar $0,576056^{2}$ X $100 \%=33,18 \%$. Promotional-mix berpengaruh 
pada Keputusan Pembelian. Semakin baik tingkat Promotional-mix maka tingkat Keputusan Pembelian akan meningkat juga. Hal ini berarti jika Prima Imaging ingin meningkatkan Keputusan Pembelian maka salah cara yang dapat dilakukan adalah dengan memberikan promosi-promosi penjualan yang menarik sehingga keputusan pembelian-nya pun dapat meningkat dan memberi dampak pada kenaikan penjualan.

\section{Situational Context $\left(\mathrm{X}_{2}\right)$ berkontribusi positif dan signifikan terhadap Keputusan Pembelian $(\mathrm{Z})$}

Hasil penelitian menunjukan bahwa Situational Context berkontribusi positif dan signifikan terhadap tinggi rendahnya Keputusan Pembelian. Besarnya kontribusi Situational Context terhadap repeat purchasing secara simultan adalah sebesar $0,410^{2}$ X $100 \%=16.81 \%$ serta besar kontribusi secara tidak langsung adalah sebesar $0,62648^{2}$ X $100 \%=39.24 \%$. Situational Context berpengaruh pada Keputusan Pembelian. Semakin baik tingkat Situational Context maka Keputusan Pembelian akan meningkat juga. Hal ini berarti Prima Imaging ingin meningkatkan keputusan pembelian maka salah satu faktor lain yang dapat dipilih adalah dengan meningkatkan Situational Context dengan cara memperhatikan kondisi lingkungan yang ada di sekitarnya, mulai dari tata ruang, ketepatan waktu serta mempekirakan sosial yang terbentuk baik pada saat melangsungkan sebuah acara ataupun pada jam operasional biasa. Dengan adanya situasi yang selalu kondusif, maka situasi tersebut dapat mempengaruhi perilaku seorang konsumen terlebih dalam hal pembuatan keputusan pembelian. Situasi pembelian yang mendukung dapat mempercepat proses pencetusan keputusan pembelian seorang konsumen.

\section{Involvement ( $(Y)$ berkontribusi positif dan signifikan terhadap Keputusan Pembelian (Z)}

Hasil penelitian menunjukan bahwa Involvement berkontribusi positif dan signifikan terhadap tinggi rendahnya Keputusan Pembelian. Besarnya kontribusi Involvement terhadap Keputusan Pembelian adalah sebesar $0,528^{2}$ X $100 \%=27,87 \%$. Salah satu tujuan dari perusahaan adalah untuk meningkatkan keterlibatan, adalah semakin banyak pelanggan yang terlibat maka pelanggan akan semakin yakin lagi dengan Prima Imaging. Keyakinan pelanggan yang tinggi terhadap Prima Imaging dapat mempermudah proses pembuatan keputusan pembelian pada Prima Imaging sehingga dapat berdampak pula terhadap point penjualan Prima Imaging dan menciptakan keuntungan.

\section{PENUTUP}

Bauran promosi dan situasi secara simultan berkontribusi secara signifikan terhadap keterlibatan konsumen. Peran keterlibatan konsumen mampu menjadi intervening antara Bauran promosi dan situasi dalam menciptakan pembelian. Industri fotografi sebaiknya memperhatikan peran bauran promosi dan situasi yang sesuai sehingga keterlibatan konsumen akan mampu diciptakan, karena sesungguhnya keterlibatan konsumen mampu menjembatani peranan keduanya untuk menghasilkan ketertarikan pada konsumen yang menentukan terjadinya pembelian aksesori fotografi. 


\section{DAFTAR PUSTAKA}

Belch, G. E., \& Belch, M. A. (2007) Advertising and promotion: An integrated marketing communications perspective.

Carrington, M. J., Neville, B. A., \& Whitwell, G. J. (2010). Journal of Business Ethics, 97,139-158.

Hawkins, D. I., Mothersbaugh, D. L. (2009). Consumer behaviour: Building marketing strategy. New York: McGraw Hill.

Kotler, P., \& Amstrong, G. (2004). Dasar-dasar pemasaran. Jakarta: Indeks.

Peter, J. P., \& Olson, J. C. (2007). Perilaku konsumen dan strategi. Jakarta: Erlangga.

Schiffman, L. G., \& Kanuk, L. L. (2007). Perilaku konsumen. Jakarta: Indeks.

Solomon, M. R. (2007). Consumer behaviour: Buying, having, and being. New Jersey: Pearson Prentice Hall.

Tjiptono, F. (2006). Strategi pemasaran. Yogyakarta: Andi.

Wardani, L. P. C. (2003). Jurnal pengaruh promosi yang efektif dalam memenangkan persaingan bebas. Jurnal Satya Dharma, 1. 